\title{
ポリ塩化ビニルのメカノケミカル脱塩素処理に関する研究
}

\section{Dechlorination of Polyvinylchloride with Mechanochemical Treatment}

\section{1.はじめに}

ポリ塩化ビニル（PVC）は，化学的, 熱的安定性に 優れ，かつ，安価であるなどの理由で，日常製品のみ ならず工業製品としても多用されている。これら製品 は，やがては廃棄されるが, これを再利用するには脱 塩素が不可欠である。本論文では，非加熱で PVC か らの脱塩素が可能なメカノケミカル $(\mathrm{MC})$ 技術に着 目し，その有効性を明確に示す基礎研究成果をまとめ た。

\section{2. 主な研究成果}

酸化物として $\mathrm{CaO}, \mathrm{Fe}_{2} \mathrm{O}_{3}, \mathrm{SiO}_{2}, \mathrm{Al}_{2} \mathrm{O}_{3}$ (それぞ れ粉末状試薬)，アルカリとして $\mathrm{KOH}, \mathrm{NaOH}$ (それ ぞれペレット状試薬）を選択し，各々一種類をPVC （粉末状試薬）に添加し, 遊星ミル（Pulverisette-7, Fritsch, Germany) を用いて, 大気圧下室温で乾式 粉砕（MC 処理）した場合の PVCの MC 脱塩素反応 について検討した。

その結果, 全ての混合系において，MC 処理により PVC は脱塩素され，PVC 骨格中には， C = C 結合が 形成されると同時に，PVCの平均分子量は，低下す ることが分かった。PVCの MC 脱塩素メカニズムは, 塩化物が生成される「反応系 $\left(\mathrm{PVC}-\mathrm{CaO},-\mathrm{Fe}_{2} \mathrm{O}_{3}\right.$, $-\mathrm{KOH},-\mathrm{NaOH}$ 系)」と $\mathrm{HCl}$ ガスが放出される「分 解系 $\left(\mathrm{PVC}-\mathrm{SiO}_{2},-\mathrm{Al}_{2} \mathrm{O}_{3}\right.$ 系) 」とに分類された。反応 系において，PVCの脱塩素率は， $\mathrm{MC}$ 処理時間およ び添加剂量の増加により向上することが分かった。

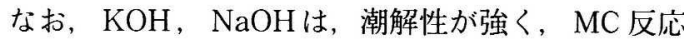
の結果として生成する水を吸収することで，自身の反 応性が低下する。このため, 上記アルカリを添加剂に 用いた PVC（塩素化 PVC を含む）の脱塩素の効率化

\section{井上 毅 (Tsuyoshi Inoue)}

積水化学工業株式会社 高機能プラスチックカンパニー 知的財産部

（テ618-8589 大阪府三島郡島本町百山 2-1）TEL 075-962-8931

Sekisui Chemical Co., Ltd.

(2-1 Momoyama, Shimamoto-cho, Mishima-gun, Osaka 618-8589, Japan)

<著者紹介>

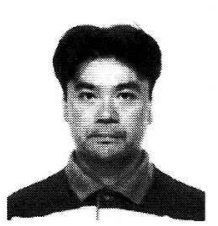

1995年早稲田大学大学院理工学研究科応用化 学専攻博士前期課程修了後, 積水化学工業 （株）入社。2002年 7 月（財）下水道新技術推 進機構出向後，2004年 7 月滋賀栗東工場復職 2007 年 4 月から現職。2006年12月博士 (学術) 取得。技術士 (上下水道部門)。

専門：化学, 粉体工学, 下水道技術
には，添加剤量の制御が重要因子であることが分かっ た。また，PVC- $\mathrm{NaOH}$ 系において，PVCに，炭化水 素樹脂（ポリエチレン，ポリプロピレン，ポリスチレ ン，ポリブタジエン）および可塑剂（フタル酸エステ ル）が存在すると, $\mathrm{MC}$ 脱塩素反応は阻害されるが, 反応そのものが変化することはなく, 添加剂量の増加 により，阻害の影響を低下できることが分かった。

最後に, MC 処理した PVC の熱分解挙動解析か ら，前処理として PVC を $\mathrm{MC}$ 処理すると，その後の 加熱工程での PVC の脱塩化水素および熱分解が容易 になり，脱塩化水素および熱分解の効率化が図れる可 能性があることが分かった。

\section{3. 研究を終えた感想と今後の展開}

本論文を通して，PVC と各種酸化物およびアルカ リの反応性と PVC の MC 脱塩素特性が明確になり, $\mathrm{MC}$ 技術は，PVCの脱塩素処理に対し有効である可 能性が示された。今後は， MC 脱塩素技術を PVC 廃 裹物の新しい処理プロセスとして確立すべく，実用化 に向けた検討を行っていく必要がある。

最後に，本研究をまとめるにあたり御懇篤なる御指 導御鞭撻を睗りました東北大学多元物質科学研究所長 の齋藤文良教授, 同研究所の加納純也講師，そして本 研究の遂行にあたり，多大なる御支援を賜りました積 水化学工業（株）の皆様に深く感謝の意を表します。

\section{文献リスト}

1) Inoue, T., et al. : “Mechanochemical Dechlorination of Polyvinyl Chloride by Co-Grinding with Various Metal Oxides", Adv. Powder Technol., 15, 215-225 (2004)

2 ) Inoue, T., et al. : "Mechanochemical Dechlorination of PVCs with Different Chlorine Contents", J. Soc. Powder Technol. Jpn., 41, 806-811 (2004)

3 ) Inoue, $T$., et al. : "Dechlorination of Polyvinyl Chloride by Its Grinding with $\mathrm{KOH}$ and $\mathrm{NaOH}^{*}$, Adv. Powder Technol., 16, 27-34 (2005)

4 ) Inoue, T., et al. : "Influence of Polymer Impurity on the Mechanochemical Dechlorination Reaction of PVC", Adv. Powder Technol., 17, 425-432 (2006)

5 ) Inoue, T., et al. : "Influence of Plastisizer on Mechanochemical Dechlorination Reaction between PVC and $\mathrm{NaOH}^{\prime}$, Soc. Chem. Eng. Jpn., 32, 215-219 (2006)

6 ) Inoue, T., et al. : "Energy Investigation on Thermal Decomposition of PVC Processed Mechanochemically with NaOH", J. Soc. Powder Technol. Jpn., 43, 20-24 (2006)

(学位取得は 2006 年 12 月, 東北大学) 